\title{
Fertilizer and Cultivar Selection of Lettuce, Basil, and Swiss Chard for Hydroponic Production
}

\author{
Hardeep Singh ${ }^{1,3}$, Bruce Dunn ${ }^{1}$, Mark Payton $^{2}$, and \\ Lynn Brandenberger ${ }^{1}$
}

ADDITIONAL INDEX WORDS. soilless culture, water-soluble fertilizer, leafy greens, chlorophyll sensors

Summary. Nutrient-film technique (NFT) trials were conducted to quantify the effect of two different water-soluble hydroponic fertilizers $(5 \mathrm{~N}-4.8 \mathrm{P}-21.6 \mathrm{~K}$ and $5 \mathrm{~N}-5.2 \mathrm{P}-21.6 \mathrm{~K}$ ) on different cultivars of lettuce (Lactuca sativa), basil (Ocimum basilicum), and swiss chard (Beta vulgaris). Results indicated swiss chard yield was affected only by cultivars, with Fordhook Giant producing the greatest fresh weight across fertilizer treatments. For lettuce production, interaction between fertilizers and cultivars was significant. 'Mirlo' and 'Rubysky' had greater growth compared with other cultivars in both fertilizers, whereas Dragoon performed well using $5 \mathrm{~N}-4.8 \mathrm{P}-21.6 \mathrm{~K}$, but not $5 \mathrm{~N}-5.2 \mathrm{P}-21.6 \mathrm{~K}$. For basil, dry weight production showed a significant interaction between fertilizers and cultivars. 'Largeleaf' produced greater dry weight with $5 \mathrm{~N}-4.8 \mathrm{P}-21.6 \mathrm{~K}$, whereas 'Lemon' produced greater dry weight with $5 \mathrm{~N}-5.2 \mathrm{P}-21.6 \mathrm{~K}$. For nutrient concentration of leaves, the concentrations were within the recommended range for lettuce when fertilized with $5 \mathrm{~N}-5.2 \mathrm{P}-21.6 \mathrm{~K}$. Nutrient concentrations varied by nutrient from the recommended range for basil, but there was no significant difference between fertilizers. For swiss chard, the nutrient concentrations were in the recommended range and there was no difference between fertilizers. Therefore, growers may need to use more than one type of fertilizer for different lettuce and basil cultivars for optimum production, whereas swiss chard cultivars can be selected based on yield regardless of fertilizer.

A very practical definition of "soilless culture" is the growth of nonaquatic plants with roots in a substrate without mineral soil, where plant nutrient needs are supplied with a nutrient solution. Soilless culture has various classification systems and methods, such as hydroponics, aeroponics, gravel culture, and rockwool culture (Maxwell, 1986). NFT was developed by Allen Cooper and his colleagues during the 1960s at the Glasshouse Crops Research Institute in Littlehampton, UK, and they defined it as a practice of growing plants in a shallow film of nutrient

Received for publication 4 Sept. 2018. Accepted for publication 13 Dec. 2018

Published online 31 January 2019

${ }^{1}$ Department of Horticulture and Landscape Architecture, $358 \mathrm{Ag}$ Hall, Oklahoma State University, Stillwater, OK 74078-6027

${ }^{2}$ Department of Statistics, 301 Math Sciences Building, Oklahoma State University, Stillwater, OK 74078-6027

${ }^{3}$ Corresponding author. E-mail: hardeep.singh@ okstate.edu.

This is an open access article distributed under the CC BY-NC-ND license (https://creativecommons.org/ licenses/by-nc-nd/4.0/).

https://doi.org/10.21273/HORTTECH04178-18 solution flowing near bare roots in a water-tight channel (Resh, 1995).

Selection of a suitable fertilizer is one of the main challenges when growing with NFT. The fertilizer used in NFT should have balanced amounts of essential elements and should not form any precipitate during its use. The plant should grow as a normal plant without facing any type of nutrient deficiency (Jones, 1982). As the nutrient solution in the NFT system recirculates, macroand micronutrients accumulate in the nutrient solution, and some of the nutrients are depleted quickly. This necessitates frequent renewal of nutrient solution, which can lead to environmental pollution resulting from the release of mineral elements if the wastewater is not treated properly (Giuffrida et al., 2002). One of the reasons for suitable fertilizer selection in hydroponics is, in field conditions to some extent, the plant can influence nutrient availability by releasing root exudates or exploring some new soil regions by growing their roots, whereas in hydroponics, all nutrients should be provided in adequate amounts unnaturally and may vary from crop to crop (Page and Feller, 2013).

There are various hydroponic fertilizers available, but the selection varies according to crop and the system used. In most studies, self-made nutrient recipes were used for growing leafy vegetables in hydroponics, including Cooper's, Imai's, Massantini's, and Hoagland's solution (Karimaei et al., 2001; Shah and Shah, 2009). This method of preparing nutrient recipes is also known as the madefrom-scratch method (Mattson and Peters, 2014). Mattson and Peters (2014) stated it is hard for small hydroponic growers to manage concentrations of nutrients while preparing their own hydroponic recipes, which has resulted in an interest in commercially prepared water-soluble fertilizers. This method is also known as the oneor two-bag approach and is suitable for hydroponic production (Mattson, and Peters, 2014; Shah, and Shah, 2009). In hydroponics, plant roots are exposed directly to the nutrient solution, whereas in soil, the conditions are different. Nutrients are not directly available to plants, and plants can influence nutrient availability (Page and Feller, 2013). Thus, if the nutrients are supplied in excess in nutrient solution, they may accumulate in the plant structure and, when consumed, may pose health

\begin{tabular}{llll}
\hline $\begin{array}{l}\text { Units } \\
\text { To convert U.S. to SI, } \\
\text { multiply by }\end{array}$ & U.S. unit & SI unit & $\begin{array}{l}\text { To convert SI to U.S., } \\
\text { multiply by }\end{array}$ \\
\hline 0.3048 & $\mathrm{ft}$ & $\mathrm{m}$ & 3.2808 \\
0.0283 & $\mathrm{ft}^{3}$ & $\mathrm{~m}^{3}$ & 35.3147 \\
3.7854 & gal & $\mathrm{L}$ & 0.2642 \\
2.54 & inch(es $)$ & $\mathrm{cm}$ & 0.3937 \\
16.3871 & inch & $\mathrm{cm}^{3}$ & 0.0610 \\
1 & $\mathrm{mmho} / \mathrm{cm}$ & $\mathrm{dS} \cdot \mathrm{m}^{-1}$ & 1 \\
1 & $\mathrm{mmho} / \mathrm{cm}$ & $\mathrm{mS} \cdot \mathrm{cm}^{-1}$ & 1 \\
28.3495 & $\mathrm{oz}$ & $\mathrm{g}$ & 0.0353 \\
0.0283 & $\mathrm{oz}$ & $\mathrm{kg}$ & 35.2740 \\
1 & $\mathrm{ppm}$ & $\mathrm{mg} \cdot \mathrm{L}^{-1}$ & 1 \\
$\left({ }^{\circ} \mathrm{F}-32\right) \div 1.8$ & ${ }^{\circ} \mathrm{F}$ & ${ }^{\circ} \mathrm{C}$ & $\left({ }^{\circ} \mathrm{C} \times 1.8\right)+32$ \\
& & &
\end{tabular}


risks (Cavarianni et al., 2008). In particular, if a food product high in nitrate is ingested, it is transformed into nitrite. Subsequently, nitrite, in combination with amines, may form carcinogenic compounds (Boink and Speijers, 1999).

Another challenge for NFT production of leafy greens is the selection of suitable cultivars. There are various studies that focus on the selection of cultivars for leafy greens in field environments, but the growth conditions in the field are incomparable with growth conditions of closed-environment culture using hydroponics. Thus, the cultivar ranking from the data derived from field experiments cannot be applied directly to cultivar selection for hydroponics (Molders et al., 2012). Vital and Teixeira (2002) evaluated different lettuce cultivars (Cinderella, Monica, Elizabeth, and Princess) and hydroponic fertilizers for shoot weight. They reported different performance of cultivars among various nutrient solutions, with cultivars Monica and Princess performing the best. Walters and Currey (2015) reported differences among basil cultivars and types, but not among hydroponic systems. Therefore, there is a need to evaluate different cultivars of leafy greens in hydroponics.

According to Ali et al. (2009), color is an influential trait for leafy greens because it affects preference and acceptability, and is also an indicator of antioxidant properties of leafy vegetables. Vittum (1963) concluded greenness of leafy vegetables is also an index for carotene content. Ferrante et al. (2004) also suggested that the color of leafy vegetables can be considered an indicator of antioxidant properties. Colonna et al. (2016) used chlorophyll meter readings [soil-plant analyses development (SPAD); Spectrum Technologies, Plainfield, IL] as an indicator of greenness for 10 different green leafy vegetables. They concluded that chlorophyll meter readings were affected by the light intensity at time of harvest, and recommended harvesting leafy vegetables during low light intensity. The objectives of our research were to evaluate the effect of two different commercial hydroponic fertilizers on growth and quality parameters of different cultivars of leafy greens (lettuce, basil, and swiss chard) in an NFT system.

\section{Materials and methods}

Plant material and growth CONDITIONS. Seeds of 'Dragoon' romaine lettuce; 'Mirlo' and 'Rex' butterhead lettuce; 'Panisse' and 'Oscarde' oakleaf lettuce; 'Ruby Sky' leaf lettuce; and 'Rainbow Chard', 'Barese', and 'Fordhook Giant' swiss chard were obtained from Johnny's Selected Seeds (Winslow, ME). Seeds of 'Large Leaf', 'Lemon', and 'Sweet' basil were obtained from W. Atlee Burpee \& Co. (Warminster, PA). Seeds were sown in rockwool starter cubes (size, $1.5 \mathrm{~cm}^{3}$ ) with 98 cubes to a sheet (Grodan, Milton, Ontario, Canada) on 12 Feb. 2016 and were transplanted into NFT tables (Hydrocycle 4-inch Pro NFT series system; Growers Supply, Dyersville, IA) on 2 Mar. 2016 at the Oklahoma State University (OSU) Department of Horticulture and Landscape Architecture Research Greenhouses in Stillwater, OK. During propagation, seedlings were shaded with $40 \%$ polyester film shadecloth (Mylar; DuPont Teijin Films, Chester, VA). When plants were moved to the NFT tables, they were not shaded. The average daily temperature, measured using a data logger (T\&D Corp., Nagano, Japan), was $27.2^{\circ} \mathrm{C}$. Light was measured using the same sensor, and the daily light integral (DLI) was calculated from these data by multiplying 9339.9 lx by 54 (the standard conversion factor for sunlight to convert lux to photosynthetic photon flux density), then multiplying 172.9 $\mu \mathrm{mol} \cdot \mathrm{m}^{-2} \cdot \mathrm{s}^{-1}$ by 0.0864 (standard conversion based on the total number of seconds in a day divided by 1 million) to obtain a DLI average of $14.9 \mathrm{~mol} \cdot \mathrm{m}^{-2} \cdot \mathrm{d}^{-1}$. No nutrition was provided during propagation. The experiment was replicated three times, with additional plantings on 15 May 2016 and 25 July 2016. Each table had 10 channels measuring 4 inches wide, 2 inches deep, and $12 \mathrm{ft}$ long. Channel lids had eighteen 13 / 8 -inch holes spaced 8 inches on center. One plant was placed in each slot and 15 plants per cultivar per table were transplanted. The NFT channels had a slope of $2.8 \%(\approx 4$ inches $/ 12 \mathrm{ft})$ between the irrigation and drainage end, and the water flowing along this slope was collected in a tank and recirculated by a pump to the irrigation pipe.
Fertilizers. Two NFT tables, with a nutrient reservoir of 45 -gal capacity $(33 \times 29 \times 12$ inches $)$ per table, were used and each was supplied with a single fertilizer of either $5 \mathrm{~N}-4.8 \mathrm{P}-21.6 \mathrm{~K}$ (J.R. Peters, Allentown, PA) or $5 \mathrm{~N}-5.2 \mathrm{P}-21.6 \mathrm{~K}$ (J.R. Peters). The fertilizers used in this experiment had different elemental compositions (Table 1). Calcium nitrate (Haifa North America, Altamonte Spring, FL) was used with the $5 \mathrm{~N}-4.8 \mathrm{P}-21.6 \mathrm{~K}$ and $5 \mathrm{~N}-5.2 \mathrm{P}-$ $21.6 \mathrm{~K}$ fertilizers because it was designed to supply calcium $(\mathrm{Ca})$ and a fraction of nitrogen $(\mathrm{N})$ through the other bag. The $\mathrm{N}$ content in the other bag was supplied so that the final $\mathrm{N}$ concentration was obtained by the addition of $\mathrm{N}$ from calcium nitrate. Tap water with an electrical conductivity (EC) of $0.5 \mathrm{mS} \cdot \mathrm{cm}^{-1}$ and a $\mathrm{pH}$ of 7.8 was used to prepare the nutrient solution. When tanks were at their 40-gal capacity, 147.41 g $5 \mathrm{~N}-4.8 \mathrm{P}-$ $21.6 \mathrm{~K}$ and $5 \mathrm{~N}-5.2 \mathrm{P}-21.6 \mathrm{~K}$, and $97.52 \mathrm{~g}$ calcium nitrate were added initially according to recommended rates.

EC, $\mathrm{PH}$, AND DATA COLLECTION. The EC of all the nutrient solutions was maintained at 1.5 to $2.5 \mathrm{dS} \cdot \mathrm{m}^{-1}$, and the $\mathrm{pH}$ was maintained at 5.5 to 6.5. The $\mathrm{pH}$ and $\mathrm{EC}$ of each solution was checked and maintained every third day. The nutrient solution $\mathrm{pH}$ was maintained using $\mathrm{pH}$ up and $\mathrm{pH}$ down solutions (General Hydroponics, Santa Rosa, CA), whereas EC was maintained by adding water if the EC was high, and adding nutrient solution in the same proportion to both bags if the EC was less than the recommended limit.

Each plant was scanned using two different chlorophyll meters (SPAD-502, Spectrum Technologies; and atLEAF, FT Green, Wilmington, $\mathrm{DE})$ at the time of harvest. For each plant, SPAD and atLEAF readings were taken from three different mature leaves from the base, middle, and top of the plant. Two plant samples from each treatment were sent for nutrient analysis after harvest. Nutrient analysis of leaf samples was analyzed by the OSU Soil, Water and Forage Analytical Laboratory in Stillwater, $\mathrm{OK}$, using a nutrient analyzer (TruSpec Carbon and Nitrogen Analyzer; LECO Corp., St. Joseph, MI). Foliar analysis was compared with recommended concentrations by Hartz 
et al. (2007) and Uchida (2000) to determine whether plant nutrient quality was within the recommended range. At the end of the study ( 5 weeks after transplanting), data were collected on shoot fresh weight and dry weight (plants were cut at the base and dried for $2 \mathrm{~d}$ at $57^{\circ} \mathrm{C}$ ).

Data analysis. The experimental design was a split-plot design with three replications over time. Factors were fertilizer (two levels) and cultivars (six levels for lettuce, three levels for basil, and three levels for swiss chard). Tests of significance were performed at the $0.05,0.001$, and 0.0001 levels. The least significance difference method was used for comparing differences between treatment means. Data analysis was generated using SAS/STAT software (version 9.4; SAS Institute, Cary, $\mathrm{NC})$.

\section{Results}

Swiss CHARD. No significant interaction was found between cultivar and fertilizer for swiss chard. Fresh weight, SPAD, and atLEAF were affected by cultivar, but dry weight of swiss chard was unaffected by cultivar and was pooled across fertilizers (Table 2). 'Fordhook Giant' had the greatest fresh weight $(296.6 \mathrm{~g})$, which was $128.4 \mathrm{~g}$ greater than 'Barese' and 77.6 g greater than 'Rainbow Chard', whereas atLEAF and SPAD reading were greater for 'Barese' (Table 3). SPAD and atLEAF readings of swiss chard varied, but 'Barese' had the greatest at 47.9 and 54.8 , respectively (Table 3 ). For swiss chard, there was not any difference in nutrient concentrations between the fertilizers, and the nutrient concentrations were in the range recommended by Hartz et al. (2007) (data not shown). SPAD and atLEAF were not correlated with $\mathrm{N}$, phosphorus $(\mathrm{P})$, and potassium (K). In swiss chard, SPAD and atLEAF were correlated with $\mathrm{Ca}$ and iron $(\mathrm{Fe})$.

LeTtuCE. There was an interaction between cultivar and fertilizer for fresh weight and dry weight in lettuce. There was no interaction for atLEAF and SPAD readings in lettuce, but both were affected by cultivar when pooled across fertilizers (Table 2). For 5N-5.2P-21.6K, Mirlo had the greatest fresh weight $(238.3 \mathrm{~g})$, which was different from all other cultivars (Fig. 1). For $5 \mathrm{~N}-$ $4.8 \mathrm{P}-21.6 \mathrm{~K}$, fresh weight of 'Mirlo'

Table 1. Nutrients concentrations of two hydroponic fertilizers when $130 \mathrm{oz}$ $(3.69 \mathrm{~kg})$ were dissolved in $1000 \mathrm{gal}(3785.4 \mathrm{~L})$ of water.

\begin{tabular}{lrc}
\hline Nutrient & $\begin{array}{r}\text { Concn for } \mathbf{5 N - 4 . 8 P - 2 1 . 6 K}+ \\
\text { calcium nitrate }(\mathbf{p p m})^{\mathbf{z}}\end{array}$ & $\begin{array}{c}\text { Concn for } \mathbf{5 N - 5 . 2 P - 2 1 . 6 K}+ \\
\text { calcium nitrate }(\mathbf{p p m})\end{array}$ \\
\hline Nitrogen & 150.00 & 150.00 \\
Phosphorus & 39.00 & 48.00 \\
Potassium & 216.00 & 216.00 \\
Calcium & 139.00 & 139.00 \\
Magnesium & 47.00 & 31.00 \\
Iron & 2.30 & 3.00 \\
Manganese & 0.38 & 0.05 \\
Zinc & 0.11 & 0.15 \\
Boron & 0.38 & 0.50 \\
Copper & 0.13 & 0.15 \\
Molybdenum & 0.07 & 0.10 \\
\hline
\end{tabular}

${ }^{\mathrm{z}} 1 \mathrm{ppm}=1 \mathrm{mg} \cdot \mathrm{L}^{-1}$

Table 2. Interaction and main effect for swiss chard ('Fordhook Giant', 'Barese', and 'Rainbow Chard'), lettuce ('Dragoon', 'Mirlo', 'Rubysky', 'Oscarde', 'Panisse', and 'Rex'), basil ('Largeleaf', 'Lemon', and 'Sweet'), and hydroponic fertilizers $(5 \mathrm{~N}-4.8 \mathrm{P}-21.6 \mathrm{~K}+$ calcium nitrate and $5 \mathrm{~N}-5.2 \mathrm{P}-21.6 \mathrm{~K}+$ calcium nitrate).

\begin{tabular}{|c|c|c|c|}
\hline & Cultivar (C) & Fertilizer $(\mathrm{F})$ & $\mathbf{C} \times \mathbf{F}$ \\
\hline \multicolumn{4}{|l|}{ Swiss chard } \\
\hline Fresh weight & $* * *$ & NS & NS \\
\hline Dry weight & NS & NS & NS \\
\hline atLEAF ${ }^{z}$ & $* * *$ & NS & NS \\
\hline SPAD $^{\mathrm{z}}$ & $* * *$ & NS & NS \\
\hline \multicolumn{4}{|l|}{ Lettuce } \\
\hline Fresh weight & $* * *$ & $* * *$ & * \\
\hline Dry weight & $* * *$ & $* * *$ & * \\
\hline atLEAF & $* * *$ & NS & NS \\
\hline SPAD & NS & NS & NS \\
\hline \multicolumn{4}{|l|}{ Basil } \\
\hline Fresh weight & NS & NS & NS \\
\hline Dry weight & * & * & ** \\
\hline atLEAF & $* * *$ & NS & $* * *$ \\
\hline SPAD & $* * *$ & * & $* *$ \\
\hline
\end{tabular}

${ }^{\mathrm{z}}$ atLEAF chlorophyll meter (FT Green, Wilmington, DE), SPAD chlorophyll meter (SPAD-502; Spectrum Technologies, Plainfield, IL).

NS, ${ }^{*},{ }^{* *},{ }^{* *}$ Nonsignificant or significant at $P \leq 0.05,0.001$, or 0.0001 , respectively.

was also the greatest $(181.1 \mathrm{~g})$, which was not different from fresh weight of 'Dragoon', 'Panisse', and 'Rubysky', but was different from 'Oscarde' and 'Rex' (Fig. 1). All cultivars, except Dragoon, had greater fresh weight with $5 \mathrm{~N}-5.2 \mathrm{P}-21.6 \mathrm{~K}$ than $5 \mathrm{~N}-$ $4.8 \mathrm{P}-21.6 \mathrm{~K}$. Mirlo had the greatest dry weight $(17.97 \mathrm{~g})$ with $5 \mathrm{~N}-5.2 \mathrm{P}-$ $21.6 \mathrm{~K}$, but there was no difference for dry weight among other cultivars with $5 \mathrm{~N}-4.8 \mathrm{P}-2 \mathrm{l} .6 \mathrm{~K}$ (Fig. 2). 'Rubysky' and 'Oscarde' had a greater dry weight with $5 \mathrm{~N}-5.2 \mathrm{P}-21.6 \mathrm{~K}$. There were no differences in dry weight for 'Panisse', 'Rex', and 'Dragoon' between fertilizers (Fig. 2). The SPAD and atLEAF readings were significantly greater for 'Dragoon', 'Mirlo', 'Oscarde', and 'Rubysky' than
Table 3. Main effect of swiss chard cultivars pooled across fertilizers (5N-4.8P-21.6K + calcium nitrate and $5 \mathrm{~N}-5.2 \mathrm{P}-21.6 \mathrm{~K}+$ calcium nitrate) for fresh weight and chlorophyll meters $(n=33)$.

\begin{tabular}{lccc}
\hline Cultivar & $\begin{array}{c}\text { Fresh } \\
\text { wt }(\mathbf{g})^{\mathrm{z}}\end{array}$ & atLEAF $^{\mathrm{y}}$ & SPAD $^{\mathrm{y}}$ \\
\hline Barese & $168.2 \mathrm{c}^{\mathrm{x}}$ & $54.8 \mathrm{a}$ & $47.9 \mathrm{a}$ \\
Fordhook & $296.6 \mathrm{a}$ & $40.8 \mathrm{~b}$ & $38.2 \mathrm{~b}$ \\
$\quad$ Giant & & & \\
$\begin{array}{c}\text { Rainbow } \\
\quad \text { Chard }\end{array}$ & $219.0 \mathrm{~b}$ & $41.4 \mathrm{~b}$ & $34.6 \mathrm{c}$ \\
\end{tabular}

${ }^{\mathrm{z}} \mathrm{lg}=0.0353 \mathrm{oz}$.

${ }^{y}$ atLEAF chlorophyll meter (FT Green, Wilmington, $\mathrm{DE})$, soil-plant analyses development (SPAD) chlorophyll meter (SPAD-502; Spectrum Technologies, Plainfield, IL).

${ }^{\mathrm{x}}$ Means within a column followed by same lowercase letter are not significantly different by least significant difference $(P \leq 0.05)$. 


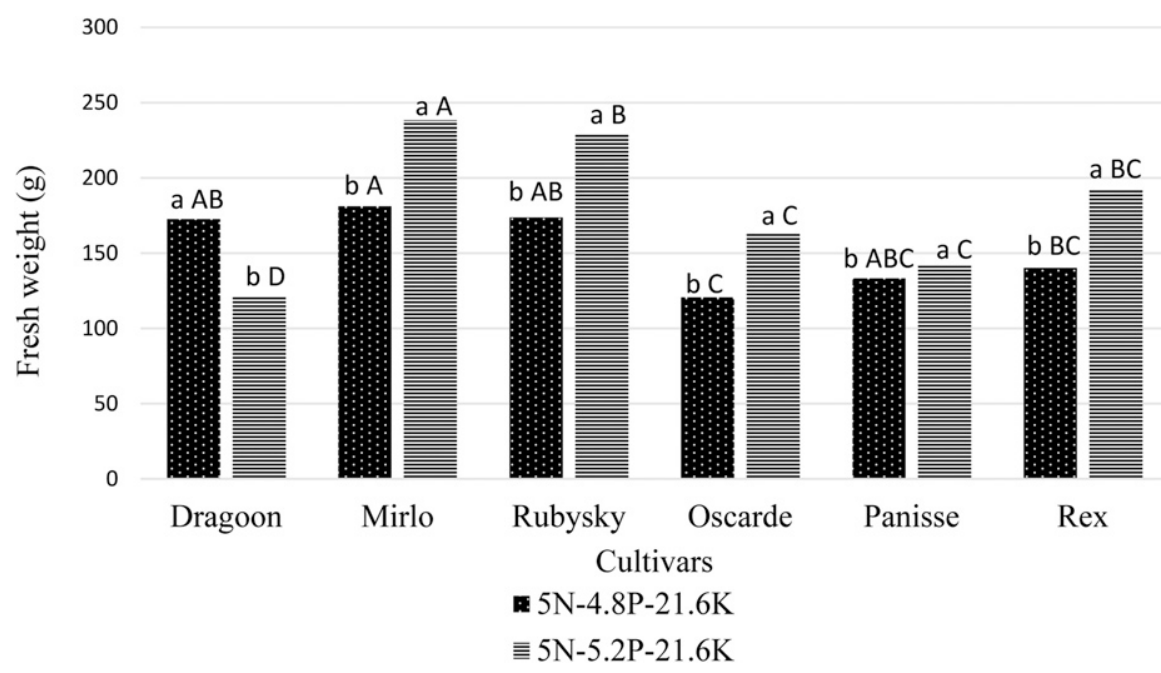

Fig. 1. Interactions among lettuce cultivars (Dragoon, Mirlo, Rubysky, Oscarde, Panisse, and Rex $)$ and hydroponic fertilizers (5N-4.8P-21.6K + calcium nitrate and $5 \mathrm{~N}-5.2 \mathrm{P}-21.6 \mathrm{~K}+$ calcium nitrate) for fresh weight. Means with the same lowercase letter are not significantly different by least significant difference (LSD; $P \leq 0.05$ ) between fertilizers within cultivars. Means with the same uppercase letter are not significantly different by LSD $(P \leq 0.05)$ among cultivars within each fertilizer. $1 \mathrm{~g}=0.0353 \mathrm{oz}$.

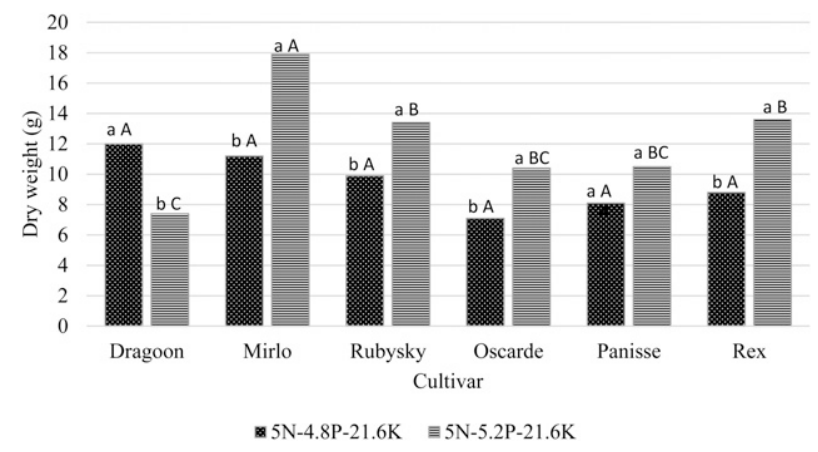

Fig. 2. Interactions among lettuce cultivars (Dragoon, Mirlo, Rubysky, Oscarde, Panisse, and Rex) and hydroponic fertilizers (5N-4.8P-21.6K + calcium nitrate and $5 \mathrm{~N}-5.2 \mathrm{P}-21.6 \mathrm{~K}+$ calcium nitrate) for dry weight. Means with the same lowercase letter are not significantly different by least significant difference (LSD; $P \leq 0.05$ ) between fertilizers within cultivars. Means with the same uppercase letter are not significantly different by LSD $(P \leq 0.05)$ among cultivars within each fertilizer. $1 \mathrm{~g}=0.0353 \mathrm{oz}$.

Table 4. Main effect of lettuce cultivars pooled across fertilizers (5N-4.8P-21.6K + calcium nitrate, and $5 \mathrm{~N}-5.2 \mathrm{P}-21.6 \mathrm{~K}+$ calcium nitrate) for chlorophyll meter readings $(n=33)$.

\begin{tabular}{llc}
\hline Cultivar & SPAD $^{\mathrm{z}}$ & atLEAF $^{\mathrm{z}}$ \\
\hline Dragoon & $27.1 \mathrm{a}^{\mathrm{y}}$ & $33.4 \mathrm{a}$ \\
Mirlo & $26.4 \mathrm{a}$ & $34.7 \mathrm{a}$ \\
Rubysky & $28.3 \mathrm{a}$ & $34.1 \mathrm{a}$ \\
Oscarde & $27.2 \mathrm{a}$ & $35.2 \mathrm{a}$ \\
Panisse & $17.2 \mathrm{c}$ & $27.8 \mathrm{c}$ \\
Rex & $19.2 \mathrm{~b}$ & $30.4 \mathrm{~b}$ \\
\hline
\end{tabular}

${ }^{\mathrm{z}}$ Soil-plant analyses development (SPAD) chlorophyll meter (SPAD-502; Spectrum Technologies, Plainfield, IL); atLEAF chlorophyll meter (FT Green, Wilmington, DE)

${ }^{y}$ Means within a column followed by same letter are not significantly different by least significant difference $(P \leq 0.05)$. cultivar and fertilizer interaction (Table 2). For $5 \mathrm{~N}-4.8 \mathrm{P}-21.6 \mathrm{~K}$, 'Largeleaf' had a greater dry weight $(18.09 \mathrm{~g})$ than 'Lemon' ( $13.53 \mathrm{~g})$ and 'Sweet' $(11.29 \mathrm{~g})$. 'Lemon' had a greater dry weight $(16.47 \mathrm{~g})$ than 'Largeleaf' $(11.10 \mathrm{~g})$ and 'Sweet' $(9.50 \mathrm{~g})$ with $5 \mathrm{~N}-5.2 \mathrm{P}-21.6 \mathrm{~K}$ (Fig. 3). 'Largeleaf' produced significantly greater dry weight $(18.09 \mathrm{~g})$ with $5 \mathrm{~N}-4.8 \mathrm{P}-$ $21.6 \mathrm{~K}$ than with $5 \mathrm{~N}-5.2 \mathrm{P}-21.6 \mathrm{~K}$ $(11.10 \mathrm{~g})$. With $5 \mathrm{~N}-4.8 \mathrm{P}-21.6 \mathrm{~K}$ and $5 \mathrm{~N}-5.2 \mathrm{P}-21.6 \mathrm{~K}$, 'Sweet' showed significantly greater SPAD and atLEAF readings compared with 'Largeleaf' and 'Lemon' (Figs. 4 and 5). 'Sweet' had greater atLEAF (39.17) and SPAD $(30.70)$ readings with $5 \mathrm{~N}-$ $4.8 \mathrm{P}-21.6 \mathrm{~K}$ compared with $5 \mathrm{~N}-$ $5.2 \mathrm{P}-21.6 \mathrm{~K}$. For basil, there was no difference in foliar nutrient concentrations between fertilizers. Comparing with recommended foliar nutrient concentrations, the amount of N, P, $\mathrm{Ca}$, zinc, and manganese (Mn) was slightly less whereas concentrations of $\mathrm{K}$ and $\mathrm{Mg}$ were greater than the recommended limit (Uchida, 2000) (Table 6). For basil, SPAD correlated negatively with $\mathrm{Na}$ and positively with sulfur $(S)$ and $\mathrm{Fe}$, whereas atLEAF correlated negatively to $\mathrm{Ca}$ (Table 7 ).

\section{Discussion}

In agreement with our study, some investigators recommended Fordhook Giant as the best cultivar for field and greenhouse production among green-leaved cultivars of swiss chard for yield in different parts of the United States (Gorman et al., 2011; Herner and Taylor, 1974; Weiss, 1983). The greater fresh weight of 'Fordhook Giant' may be the result of genetic characteristics such as large leaf size. Pokluda and Kuben (2002) reported a mean fresh weight of $248 \mathrm{~g}$ for 'Fordhook Giant', which was slightly less than 'Bright Lights'. According to Maboko and Du Plooy (2008), yield of 'Fordhook Giant' was also affected by planting density in a closed hydroponic system. They recommended a planting density of 40 plants $/ \mathrm{m}^{2}$.

For lettuce, an interaction between hydroponic solutions and cultivars was reported in previous studies. Vital and Teixeira (2002) reported an interaction between lettuce cultivars (Cinderella, Monica, Elizabeth, and Princess) and hydroponic fertilizers for shoot weight. This 
Table 5. Foliar nutrient concentration for lettuce in comparison with recommended nutrient level by Hartz et al. (2007) $(\mathrm{n}=18)$.

\begin{tabular}{|c|c|c|c|}
\hline Nutrient $^{\mathrm{z}}$ & $\begin{array}{c}\text { Foliar concn for } \\
5 \mathrm{~N}-4.8 \mathrm{P}-21.6 \mathrm{~K}+ \\
\text { calcium nitrate }\end{array}$ & $\begin{array}{l}\text { Foliar concn for } \\
5 \mathrm{~N}-5.2 \mathrm{P}-21.6 \mathrm{~K}+ \\
\text { calcium nitrate }\end{array}$ & $\begin{array}{c}\text { Recommended } \\
\text { foliar concn } \\
\end{array}$ \\
\hline Nitrogen (\%) & $4.84 \mathrm{a}^{\mathrm{y}}$ & $4.64 \mathrm{a}$ & $3.80-5.00$ \\
\hline Phosphorus* $(\%)$ & $1.00 \mathrm{a}$ & $0.58 \mathrm{~b}$ & $0.45-0.60$ \\
\hline Potassium $* * *(\%)$ & $5.38 \mathrm{a}$ & $6.20 \mathrm{~b}$ & $5.50-6.20$ \\
\hline Calcium (\%) & $1.21 \mathrm{a}$ & $1.23 \mathrm{a}$ & $2.00-2.80$ \\
\hline Magnesium* (\%) & $0.63 \mathrm{a}$ & $0.52 \mathrm{~b}$ & $0.60-0.80$ \\
\hline Sulfur (\%) & $0.30 \mathrm{a}$ & $0.29 \mathrm{a}$ & $0.25-0.30$ \\
\hline Boron (ppm) & $58.33 \mathrm{a}$ & $48.00 \mathrm{a}$ & $25-60$ \\
\hline Zinc (ppm) & $68.00 \mathrm{a}$ & $67.47 \mathrm{a}$ & $55-70$ \\
\hline Manganese (ppm) & $132.75 \mathrm{a}$ & $106.66 \mathrm{a}$ & $11-250$ \\
\hline Iron (ppm) & $109.82 \mathrm{a}$ & $92.90 \mathrm{a}$ & $40-100$ \\
\hline Copper* $(\mathrm{ppm})$ & $12.94 \mathrm{a}$ & $9.30 \mathrm{~b}$ & $7-10$ \\
\hline
\end{tabular}

${ }^{\mathrm{z}} \mathrm{l} \mathrm{ppm}=1 \mathrm{mg} \cdot \mathrm{L}^{-1}$

${ }^{\mathrm{y}}$ Means within a row followed by same letter are not significantly different by least significant difference $(P \leq 0.05)$. ${ }^{*}, * *, * *$ Significant at $P \leq 0.05,0.001$, or 0.0001 , respectively.

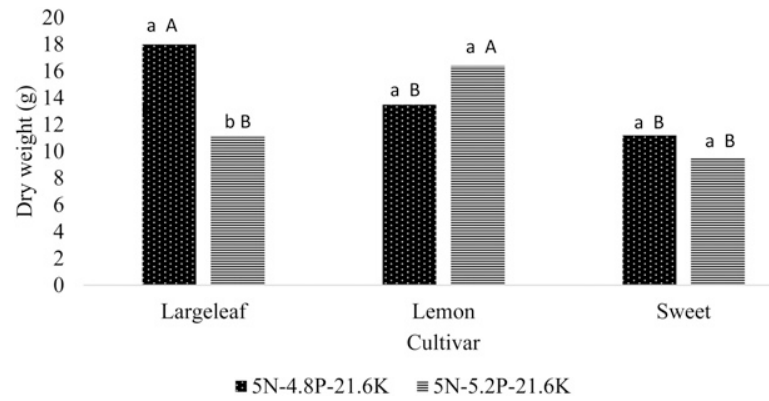

Fig. 3. Interactions among basil cultivars (Largeleaf, Lemon, and Sweet) and hydroponic fertilizers $(5 \mathrm{~N}-4.8 \mathrm{P}-21.6 \mathrm{~K}+$ calcium nitrate and $5 \mathrm{~N}-5.2 \mathrm{P}-21.6 \mathrm{~K}+$ calcium nitrate) for dry weight. Means with the same lowercase letter are not significantly different by least significant difference (LSD; $P \leq 0.05$ ) between fertilizers within cultivars. Means with the same uppercase letter are not significantly different by LSD $(P \leq 0.05)$ among cultivars within each fertilizer. $1 \mathrm{~g}=0.0353 \mathrm{oz}$.

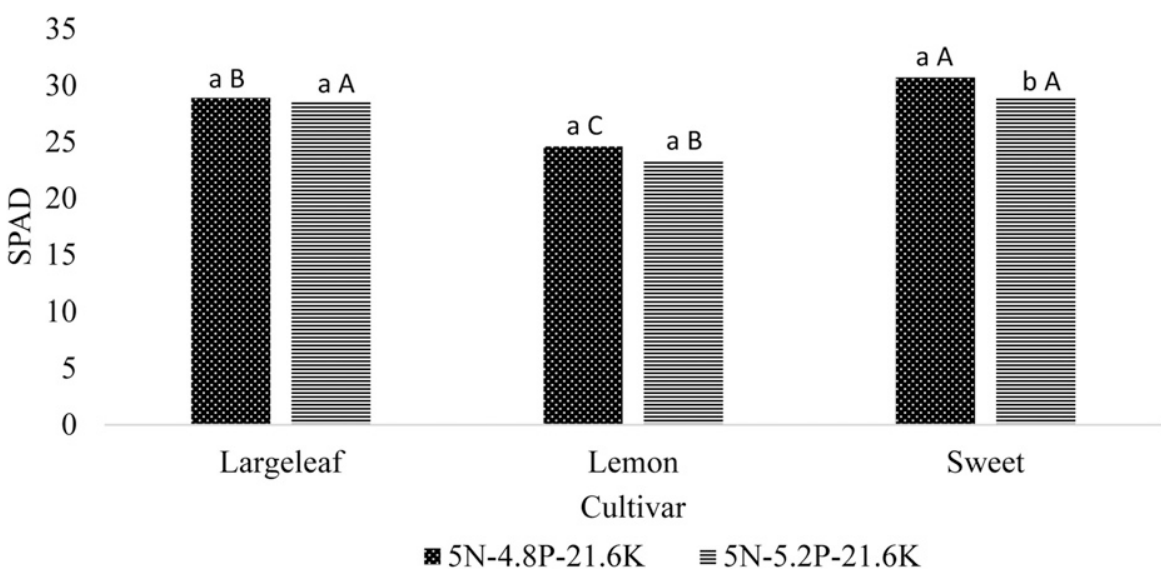

Fig. 4. Interactions among basil cultivars (Largeleaf, Lemon, and Sweet) and hydroponic fertilizers $(5 \mathrm{~N}-4.8 \mathrm{P}-21.6 \mathrm{~K}+$ calcium nitrate and $5 \mathrm{~N}-5.2 \mathrm{P}-21.6 \mathrm{~K}$ + calcium nitrate) for soil-plant analysis development (SPAD) chlorophyll meter (SPAD-502; Spectrum Technologies, Plainfield, IL) readings. Means with same lowercase letter are not significantly different by least significant difference (LSD; $P \leq 0.05)$ between fertilizers within cultivars. Means with the same uppercase letter are not significantly different by LSD $(P \leq 0.05)$ among cultivars within each fertilizer. corresponded to our results, which showed that cultivar performance varied in different nutrient solutions, but among cultivars, Monica and Princess were best.

'Largeleaf' and 'Lemon' basil were best suited for the NFT system as a result of their morphological characteristics such as short internodes, large leaves, and high branching, which prevents lodging (Walters and Currey, 2015). This supports our results as 'Largeleaf' produced greater dry weight with $5 \mathrm{~N}-4.8 \mathrm{P}-21.6 \mathrm{~K}$, whereas 'Lemon' produced similar dry weight with $5 \mathrm{~N}-4.8 \mathrm{P}-21.6 \mathrm{~K}$ and $5 \mathrm{~N}-5.2 \mathrm{P}-21.6 \mathrm{~K}$ (Fig. 3 ). In our experiment, atLEAF readings were greater than SPAD readings for all basil cultivars, but were correlated positively (Table 6), which corresponds to the findings of Dunn and Goad (2015), who noted that both sensors were correlated and had an average difference of 5.5 with a reading of atLEAF greater than SPAD in ornamental cabbage (Brassica oleracea var. capitata).

The correlation between chlorophyll meters and $\mathrm{N}$ concentrations is not always clear, and no correlation has been reported in some previous studies. Altland et al. (2002) concluded SPAD readings were not a good estimate of plant $\mathrm{N}$ status in vinca (Catharanthus roseus). Westerveld et al. (2002) reported SPAD is not a suitable instrument for estimating leaf $\mathrm{N}$ content in carrot (Daucus carota) and onion (Allium sp.). Rodriguez and Miller (2000) reported limited use of SPAD for estimating leaf $\mathrm{N}$ concentration in st. augustinegrass (Stenotaphrum secundatum). One of the reasons behind this noncorrelation of SPAD and atLEAF with $\mathrm{N}$ concentration may be that chlorophyll content in some crops may differ because of a deficiency in nutrients such as Fe, S, Mg, and Mn (Masoni et al., 1996). Recently, Dunn et al. (2018) reported SPAD and atLEAF readings were affected by the presence or absence of $\mathrm{P}$ and $\mathrm{K}$ in leaves of 'Vista Red' salvia (Salvia splendens).

\section{Conclusions}

Based on our results, 'Fordhook Giant' is the greatest-producing cultivar of swiss chard on the basis of fresh weight, whereas fertilizer had no effect on swiss chard. 'Barese' had greater sensor readings compared with 


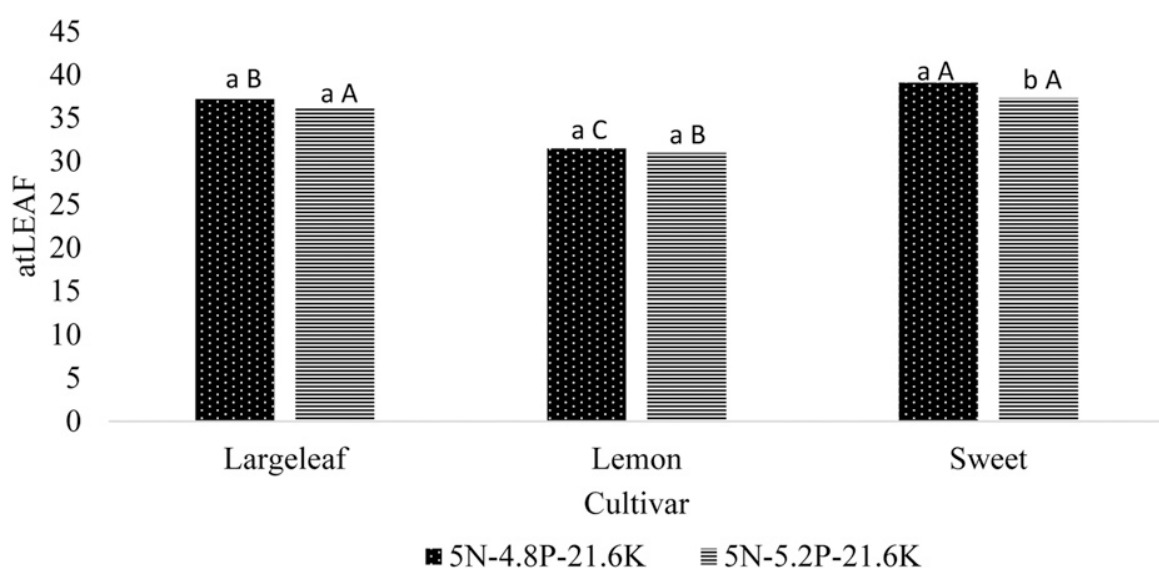

Fig. 5. Interactions among basil cultivars (Largeleaf, Lemon, and Sweet) and hydroponic fertilizers $(5 \mathrm{~N}-4.8 \mathrm{P}-21.6 \mathrm{~K}+$ calcium nitrate and $5 \mathrm{~N}-5.2 \mathrm{P}-21.6 \mathrm{~K}$ + calcium nitrate) for atLEAF chlorophyll meter (FT Green, Wilmington, DE) readings. Means with the same lowercase letter are not significantly different by least significant difference (LSD; $P \leq 0.05$ ) between fertilizers within cultivars. Means with the same uppercase letter are not significantly different by LSD ( $P \leq$ 0.05 ) among cultivars within each fertilizer.

Table 6. Foliar nutrient concentration for basil in comparison with recommended nutrient level by Uchida $(2000)(n=9)$.

\begin{tabular}{lccc}
\hline & $\begin{array}{c}\text { Foliar concn for } \\
\mathbf{5 N - 4 . 8 P - 2 1 . 6 K}+ \\
\text { calcium nitrate }\end{array}$ & $\begin{array}{c}\text { Foliar concn for } \\
\mathbf{5 N - 5 . 2 P - 2 1 . 6 K}+ \\
\text { calcium nitrate }\end{array}$ & $\begin{array}{c}\text { Recommended } \\
\text { foliar concn } \\
\text { (mean } \pm \text { SD) }\end{array}$ \\
\hline Nitrogen (\%) & $4.18 \mathrm{a}^{\mathrm{y}}$ & $4.30 \mathrm{a}$ & $5.21 \pm 0.11$ \\
Phosphorus (\%) & $1.31 \mathrm{a}$ & $1.28 \mathrm{a}$ & $1.63 \pm 0.05$ \\
Potassium (\%) & $4.56 \mathrm{a}$ & $5.12 \mathrm{a}$ & $0.69 \pm 0.02$ \\
Calcium (\%) & $1.92 \mathrm{a}$ & $2.10 \mathrm{a}$ & $2.92 \pm 0.13$ \\
Magnesium $(\%)$ & $0.78 \mathrm{a}$ & $0.56 \mathrm{a}$ & $0.45 \pm 0.02$ \\
Sulfur (\%) & $0.32 \mathrm{a}$ & $0.32 \mathrm{a}$ & $0.30 \pm 0.01$ \\
Boron (ppm) & $37.49 \mathrm{a}$ & $36.84 \mathrm{a}$ & $37.60 \pm 1.6$ \\
Zinc (ppm) & $40.53 \mathrm{a}$ & $39.23 \mathrm{a}$ & $65.40 \pm 2.2$ \\
Manganese $(\mathrm{ppm})$ & $74.75 \mathrm{a}$ & $76.44 \mathrm{a}$ & $92.70 \pm 3.6$ \\
Iron (ppm) & $69.46 \mathrm{a}$ & $56.03 \mathrm{a}$ & $99.10 \pm 3.8$ \\
Copper $(\mathrm{ppm})$ & $10.24 \mathrm{a}$ & $10.74 \mathrm{a}$ & $15.90 \pm 0.74$ \\
\hline
\end{tabular}

${ }^{\mathrm{z}} 1 \mathrm{ppm}=1 \mathrm{mg} \cdot \mathrm{L}^{-1}$.

${ }^{\mathrm{y}}$ Means within a row followed by same letter are not significantly different by least significant difference $(P \leq 0.05)$.

Table 7. Significant correlations of different foliar nutrient concentration for swiss chard ('Fordhook Giant', 'Barese', and 'Rainbow Chard'), lettuce ('Dragoon', 'Mirlo', 'Rubysky', 'Oscarde', 'Panisse', and 'Rex'), and basil ('Largeleaf', 'Lemon', and 'Sweet') pooled across hydroponic fertilizers (5N-4.8P-21.6K + calcium nitrate and $5 \mathrm{~N}-5.2 \mathrm{P}-21.6 \mathrm{~K}+$ calcium nitrate) with chlorophyll meter readings $(n=18)$.

\begin{tabular}{lcccccc}
\hline Nutrient & $\begin{array}{c}\text { Basil } \\
\text { SPAD }^{z}\end{array}$ & $\begin{array}{c}\text { Basil } \\
\text { atLEAF }\end{array}$ & $\begin{array}{c}\text { Lettuce } \\
\text { SPAD }\end{array}$ & $\begin{array}{c}\text { Lettuce } \\
\text { atLEAF }\end{array}$ & $\begin{array}{c}\text { Swiss } \\
\text { chard } \\
\text { SPAD }\end{array}$ & $\begin{array}{c}\text { Swiss } \\
\text { chard } \\
\text { atLEAF }\end{array}$ \\
\hline Calcium & -0.356 & $-0.410^{*}$ & -0.152 & -0.004 & $0.568^{*}$ & $0.517^{*}$ \\
Sodium & $-0.632^{* *}$ & $-0.690^{* *}$ & $-0.604^{* * *}$ & $-0.452^{*}$ & -0.331 & -0.347 \\
Sulfur & $0.644^{* *}$ & $0.6147^{* *}$ & -0.070 & -0.078 & 0.104 & 0.093 \\
Iron & $0.695^{* *}$ & $0.724^{* *}$ & 0.069 & 0.107 & $0.444^{*}$ & $0.464^{*}$ \\
SPAD & & $0.978^{* *}$ & & $0.721^{* * *}$ & & $0.776^{* * *}$ \\
\hline
\end{tabular}

${ }^{\mathrm{z}}$ Soil-plant analyses development (SPAD) chlorophyll meter (SPAD-502; Spectrum Technologies, Plainfield, IL); atLEAF chlorophyll meter (FT Green, Wilmington, DE).

${ }^{*},{ }^{*},{ }^{* *}$ Significant at $P \leq 0.05,0.001$, or 0.0001 , respectively. other cultivars of swiss chard, and may have greater nutritional value. For lettuce, 'Dragoon', 'Mirlo', and 'Rubysky' are well suited for production in NFT based on growth and color. For basil, 'Largeleaf' and 'Sweet' are recommended for $5 \mathrm{~N}-4.8 \mathrm{P}-21.6 \mathrm{~K}$, whereas 'Lemon' is recommended for both $5 \mathrm{~N}-4.8 \mathrm{P}-21.6 \mathrm{~K}$ and $5 \mathrm{~N}-5.2 \mathrm{P}-$ $21.6 \mathrm{~K}$ in hydroponics. Looking at SPAD and atLEAF data, high-yielding cultivars of all three crops had less chlorophyll content compared with low-yielding cultivars. In terms of nutrient concentration of leaves, the levels were within range for lettuce when fertilized with $5 \mathrm{~N}-5.2 \mathrm{P}-21.6 \mathrm{~K}$; nutrient levels were a little outside the recommended ranges for basil, but there was no significant difference between fertilizers. For swiss chard, the nutrient levels were within recommended ranges and there was no difference between fertilizers. Future research should investigate other cultivars suitable for hydroponics using these fertilizers, or should evaluate other fertilizers for these cultivars.

\section{Literature cited}

Ali, M.B., L. Khandaker, and S. Oba. 2009. Comparative study on functional components, antioxidant activity and color parameters of selected colored leafy vegetables as affected by photoperiods. J. Food Agr. Environ. 7:392-398.

Altland, J.E., C.H. Gilliam, J.H. Edwards, G.J. Keever, D.C. Fare, and J.L. Sibley. 2002. Rapid determination of nitrogen status in annual vinca. J. Environ. Hort. 20:189-194.

Boink, A. and G. Speijers. 1999. Health effects of nitrates and nitrite: A review. Acta Hort. 563:29-36.

Cavarianni, R.L., A.B. Cecílio Filho, J.O. Cazetta, A. May, and M.M. Corradi. 2008. Nutrient contents and production of rocket as affected by nitrogen concentrations in the nutritive solution. Sci. Agr. 65:652-658

Colonna, E., Y. Rouphael, G. Barbieri, and S. De Pascale. 2016. Nutritional quality of ten leafy vegetables harvested at two light intensities. Food Chem. 199:702-710.

Dunn, B.L. and C. Goad. 2015. Effect of foliar nitrogen and optical sensor sampling method and location for determining ornamental cabbage fertility status. HortScience 50:74-77.

Dunn, B.L., H. Singh, M. Payton, and S. Kincheloe. 2018. Effects of nitrogen, 
phosphorus, and potassium on SPAD502 and atLEAF sensor readings of Salvia. J. Plant Nutr. 4:1-10.

Ferrante, A., L. Incrocci, R. Maggini, G. Serra, and F. Tognoni. 2004. Colour changes of fresh-cut leafy vegetables during storage. J. Food Agr. Environ. 2:4044.

Giuffrida, F., V. Lipari, and C. Leonardi. 2002. A simplified management of closed soilless cultivation systems. Acta Hort. 614:155-160.

Gorman, R.F., J. Smeenk, and D. Snyder. 2011. Recommended variety list for southeastern Alaska. Univ. Alaska Fairbanks Coop. Ext. Serv. HGA-00231.

Hartz, T.K., P.R. Johnstone, E. Williams, and R.F. Smith. 2007. Establishing lettuce leaf nutrient optimum ranges through DRIS analysis. HortScience 42:143146.

Herner, R.C. and J.L. Taylor. 1974. Home vegetable garden variety recommendations. Michigan State Univ. Coop. Ext. Serv. E-760(a).

Jones, J.B., Jr. 1982. Hydroponics: Its history and use in plant nutrition studies. J. Plant Nutr. 5:1003-1030.

Karimaei, M.S., S. Massiha, and M. Mogaddam. 2001. Comparison of two nutrient solutions' effect on growth and nutrient levels of lettuce (Lactuca sativa) cultivars. Acta Hort. 644:69-76.

Maboko, M.M. and C.P. Du Plooy. 2008. Evaluation of crisphead lettuce cultivars (Lactuca sativa) for winter production in a soilless production system. Afr. J. Plant Sci. 2:113-117.
Masoni, A., L. Ercoli, and M. Mariotti. 1996. Spectral properties of leaves deficient in iron, sulfur, magnesium, and manganese. Agron. J. 88:937-943.

Mattson, N.S. and C. Peters. 2014. A recipe for hydroponic success. Inside Grower 2014(Jan.):16-19.

Maxwell, K. 1986. Soilless (hydroponic) culture: The past, present and future: An Australian viewpoint. Soilless Cult. 2:2734.

Molders, K., M. Quinet, J. Decat, B. Secco, E. Dulière, S. Pieters, T. van der Kooij, S. Lutts, and D. van der Straeten. 2012. Selection and hydroponic growth of potato cultivars for bioregenerative life support systems. Adv. Space Res. 50:156165.

Page, V. and U. Feller. 2013. Selection and hydroponic growth of bread wheat cultivars for bioregenerative life support systems. Adv. Space Res. 52:536-546.

Pokluda, R. and J. Kuben. 2002. Comparison of selected swiss chard (Beta vulgaris ssp. cicla) varieties. Hort. Sci. (Prague) 29:114-118.

Resh, H.M. 1995. Hydroponic food production. 5th ed. Woodbridge Press, Santa Barbara, CA.

Rodriguez, I.R. and G.L. Miller. 2000. Using a chlorophyll meter to determine the chlorophyll concentration, nitrogen concentration, and visual quality of st. augustinegrass. HortScience 35:751754.

Shah, A.H. and S.H. Shah. 2009. Cultivation of lettuce in different strengths of the two nutrients solution recipes in a non-circulating hydroponics system. J. Agron. 25:419-428.

Uchida, R. 2000. Recommended plant tissue nutrient levels for some vegetable, fruit, and ornamental foliage and flowering plants in Hawaii, p. 57-64. In: J.A. Silva and R. Uchida (eds.). Plant nutrient management in Hawaii's soils. College Tropical Agr. Human Resources, Univ. Hawaii at Manoa, Honolulu, HI.

Vital, W.M. and N.T. Teixeira. 2002. Behavior of varieties of lettuce (Lactuca sativa) cultivated in hydroponics with different nutritional solutions. Ecosystem $27: 2$.

Vittum, M.T. 1963. Effect of fertilizers on the quality of vegetables. Agron. J. 55: 425-429.

Walters, K.J. and C.J. Currey. 2015. Hydroponic greenhouse basil production: Comparing systems and cultivars. HortTechnology 25:645-650.

Weiss, K. 1983. Selected vegetable varieties for Nebraska. Nebraska Coop. Ext. Serv. EC83-1242.

Westerveld, S.M., A.W. McKeown, M.R. McDonald, and C.D. Scott-Dupree. 2002. Chlorophyll and nitrate meters as nitrogen monitoring tools for selected vegetables in southern Ontario. XXVI Intl. Hort. Congr. 627:259-266. 